\title{
Water and health at the household level in Eastern Lima, Peru: an urban ecosystem approach
}

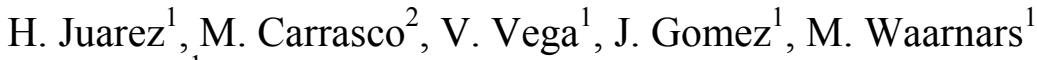 \\ $\&$ G. Prain ${ }^{1}$ \\ ${ }^{1}$ Urban Harvest - Centro Internacional de la Papa (CIP), Peru \\ ${ }^{2}$ Instituto de Investigación Nutricional (IIN), Peru
}

\begin{abstract}
The rapid population increase in Lima is leading to an expansion of unplanned informal settlements that lack a number of urban services including waste management, clean water and drainage systems. Using an urban ecosystem health approach, the study sought to identify the most relevant factors that affect child health related to water at the household level in two communities in eastern Lima.

Workshops, semi-structured surveys, interviews and observations were used as mechanisms to promote health awareness, education and understanding. Weekly or bi-weekly diarrhea surveillance was performed. Excreta samples were collected to determine the presence of parasites in children. Water samples of open hand-dug wells were collected for fecal coliforms and human parasites analysis.

Hand-dug wells, used by most people as domestic water, were found to be highly contaminated with fecal matter ( $99 \%$ of samples). Poor sanitary practices appear to be the main reason for nearly three quarters of children being infested with human protozoa.
\end{abstract}

Through participatory decision-making, the communities identified improvements in domestic water quality using filters as their priority. Community members themselves were involved in building household slowsand filters, encouraging hand washing by washtub installation, and closing the exposed wells to prevent external contamination. Education on health, environment and hygiene encouraged these behavioral changes.

Slow-sand filters had a significant improvement on water quality, with a removal of up to $96.9 \%$ of fecal coliform contamination. Nevertheless, after medical treatment for protozoa removal, laboratory results showed protozoa reinfection in more than $60 \%$ of children. These results suggest the water is not the only way children become infected with human protozoa. However, $90 \%$ of families perceived that the incidence of water borne disease, especially in children, had dropped remarkably since they used the filter.

An analysis of interactions between the social conditions of poor shanty town dwellers, their access to and use of domestic water, and the disease burden of children in these communities identify the use of shallow wells as an important potential source of ill-heath. Breaking this cycle through the use of simple filtering technology has had positive effects on health, especially of children.

Keywords: urban ecohealth approach, drinking water quality, slow sand filtration, hand-dug wells. 


\section{Introduction}

Human health cannot be considered in clinical isolation. It very much depends on the quality of the environment in which people live; for people to be healthy, they need healthy environments. The perspective known as Ecosystem Approaches to Human Health (Ecohealth) emerged in response to recognition that health and wellbeing are embedded within ecosystems. Ecohealth initiatives are characterised by integrated approaches to health and environmental issues, where priority is given to participatory and interdisciplinary research that is conscious of social and gender equity. Research in Ecohealth brings together researchers in natural sciences, health sciences, and social sciences, who work in direct collaboration with interested parties, political decision makers and stakeholders.

Water is not only a basic need for life, but also a human right according to the United Nations. Consumption of unsafe water causes gastrointestinal illnesses that kill more than 2 million people annually. Nevertheless, developing safe, piped potable water supplies and systems that will take decades to achieve, even though an important international health goal. In the meantime, more than one billion people worldwide, including a large segment of the population of Peru, remain without access to improved, safe water. There are urgent needs in Peru and many other developing countries to improve such access and thereby reduce the global burden of waterborne disease.

The rapid growth of population in Lima is leading to an expansion of unplanned informal settlements, which lack many basic urban services such as waste management, clean water and drainage. Lima is one of many large cities in the world, which are located at the mouth of rivers, which are conduits for different kinds of environmental problems that directly impact on water quality. Typically, such water is polluted by agro-chemical runoff (such as fertilizers and pesticides) as well as mining discharges that affect both the ecosystem and the public's health $[6,7]$.

The Rímac River basin is one of the most important in Peru. It provides drinking water for approximately $60 \%$ of Lima's population of about 8 million people. The river supplies a large population with a wide range of socioeconomic activities including mining, an industry established long ago in the upper and middle part of the basin. In addition, hydroelectric generation occurs along the river, as well as agricultural irrigation.

Water contamination of the Rímac River historically has been related to the discharge of mining waste in the upper and middle part of the basin $[3,5,6,10]$. Additionally, the rapid and unplanned growth of human settlements around the river aggravates this situation, contaminating the river with enteric pathogens $[1,2,6,8,9,12,13]$.

Safe water supplies are lacking in many communities along the Rimac River, as many people in both suburban and rural areas must manually collect and use untreated water for their households. Using an urban ecosystem health approach, the main objectives of this study were to identify the most relevant water-related factors that affect child health at the household level in two communities in 
eastern Lima, and to contribute to the reduction of waterborne disease affecting young children through a participatory community-based decision-making approach.

\section{Methods}

\subsection{Baseline studies}

\subsubsection{Community selection, recruitment and participation}

The study was conducted in two communities in the peri-urban areas of eastern Lima that lack access to piped water. 27 de Junio is a shantytown and MonteLindero Bajo is a horticultural community. Both communities are located along the Rímac River, have access to water from hand-dug wells near their homes and provide an ideal situation to reduce waterborne diarrheal disease.

Workshops, focus groups, semi-structured surveys, interviews and observations were used as mechanisms to promote health awareness, education and understanding. The workshops focused on identifying the principal health, environment and hygiene perceived in the communities. Semi-structured surveys were used for population characterization and identification of baseline data on socio-economic status as well as health and hygiene information on the households. Interviews were conducted with mothers of children less than 10 years old. Detailed field observation was collected after interventions of typical water collection and storage as well as hygiene practices.

\subsubsection{Excreta sampling and follow-up}

The study households were monitored for levels of diarrheal disease. Weekly or bi-weekly diarrhea surveillance was performed. A pre-tested, structured questionnaire was used in the assessment of prevalence and incidence of diarrheal illness during the study period.

Excreta samples were collected to determine presence of parasites in children (March, 2007). Every mother was provided with three plastic containers to obtain excreta on three consecutive days. The samples were conserved in formalin, merthiolate and iodine. The parasitological analysis was based on flotation and concentration.

\subsubsection{Water sampling}

Water samples of 23 open hand-dug wells were collected in December 2006 for fecal coliforms and human parasites analysis. Water samples were collected in sterilized glassware containers. Each sample was geo-referenced by a GPS location. To assess the contamination status of water, the General Water Law of Peru was consulted [11]. Maps were used to present and analyze spatially the results.

\subsection{Participatory processes for interventions}

A workshop was held in May 2007 to discuss the information compiled in the diagnosis and probable solutions in their context. The interventions discussed 
were installation of elevated tank and condominium water system; installation of household slow sand filters; setting up of washtubs; and protection of the open wells.

Through a participatory decision-making process, the communities identified improvements in domestic water quality using slow-sand filters as their priority. Once this decision was taken, community members themselves became directly involved in building the household-scale filters, encouraging hand washing by washtub installation, and closing the exposed wells to prevent external contamination.

Educational sessions were held which focused on key hygiene messages. Three hygiene-related actions to protect infants against diarrhea were encouraged: washing hands before preparing food and after using the toilet, safely disposing of infant faeces, and safely storing water in the house to prevent microbial re-contamination (narrow mouth storage container coupled to the filter).

The project facilitated des-parasitization treatment of children with positive results from fecal sampling. We used 'Metronidazole' three times a day over seven consecutive days for protozoa removal.

Sampling of randomly selected households determined the microbiological quality of their drinking water and the levels of household diarrheal disease (based on data gathered using a questionnaire). Water samples were collected in August $2007(n=20)$, December $2007(n=29)$ and March $2008(n=28)$ from the hand-dug wells and the spouts of filters to asses the efficiency of reduction of bacterial contamination.

\section{Results and discussion}

Women play a major role in domestic water management in areas where safe water and drainage are not available in the house. In these settings, women are typically responsible for collecting, storing, and using water and for disposing of wastewater. In 27 de Junio and Lindero-Monte Bajo, water from open wells is available, and no absolute shortage of water exists. However, safely disposing of wastewater and toilet effluent often remains a difficulty, exacerbated by the high water table associated with the irrigation system.

Hand-dug wells, used by most people as the main source of domestic water, were found to be highly contaminated with fecal matter ( $99 \%$ of samples). The study suggested the river as the major source of pollution. However, surface contamination of the uncovered wells and excreta disposal in pit latrines or open fields are also plausible causes. Poor sanitary practices appear to be the main reason for nearly three quarters of children being infested with human protozoa (Giardia lamblia and Blastocystis hominis).

Through participatory decision-making, the communities identified improvements in domestic water quality using filters as their priority. Community members themselves were involved in building household slowsand filters, encouraging hand washing by washtub installation, and closing the 
exposed wells to prevent external contamination. Education on health, environment and hygiene encouraged these behavioural changes.

Well protection did not have a significant effect on the bacterial water quality. Results suggest that the principal source of pollution is the Rímac River and not the environment, as was expected. The riverbed filters a portion of the highly contaminated bacteria and parasites as it percolates through to the wells. However, healthiness is also about perception. In both communities, people considered that protecting wells is a factor in their safety. As one woman said, "The well is cleaner and there are no more algae, no longer garbage, there are no toads nor papers, no longer objects such as chicken feathers, nor dirt."

These results suggest that community perception about water quality is attributed mainly to factors that are easily observed. If the exposure is not visible (for instance, the presence of parasites, pathogens or other dissolved pollutants), the perception to that exposure is less apparent $[4,6]$.

The implementation of slow-sand filters had a significant improvement on the water quality (Figure 1). The better results were obtained in the community of 27 de Junio. The water quality of wells in 27 de Junio was on average 756 MNP of $\mathrm{CF} / 100 \mathrm{ml}$ and without detectable human parasites. After filter treatment, water was on average $11 \mathrm{MNP}$ of $\mathrm{CF} / 100 \mathrm{ml}$. This represents a bacterial removal of over $98.6 \%$. Although a smaller bacterial removal $(77.4 \%)$ was observed in Lindero-Monte Bajo, this was due to the fact that water quality of their wells was initially much better (123 MNP of CF/100 ml). Additionally, women recognized that treated water from the filters "improves the flavour...there are no more insects or fine sand, and it is more crystalline and cleaner."

Nevertheless, after medical treatment for protozoa removal, laboratory results showed protozoa re-infection in more than $60 \%$ of children who still carry infestations of Giardia lamblia (70\%) and Blastocystis hominis (40\%). This study suggests the water is not the only way children become infected with human protozoa. Diseases resulting from fecal-oral transmission can also be caused by other hygienic practices. Participatory observation of household practices and behaviours noted the children play habits, crawling on the ground where animal droppings were often also observed. General good hygiene and excreta disposal practices are important, as well as an adequate quantity of water [14]. Other sources of contamination seen in the communities are small-scale animal production in which many families are involved and the contaminated irrigation canals near the households where children play.

However, $90 \%$ of members of the interviewed households perceived that the incidence of water borne disease, especially in children, had dropped remarkably since they used a filter. The mothers noted significantly less diarrhea episodes in their children. The frequency of diarrhea collected through bi-weakly surveillance showed that half of the children $(n=26)$ did not present diarrhea episodes after the intervention. As mothers stated, "By taking water from the well we suffered stomach cramps, but now we have a healthier stomachs. My young child had diarrhea three times a day, but now I feel he is better with less diarrhea". 

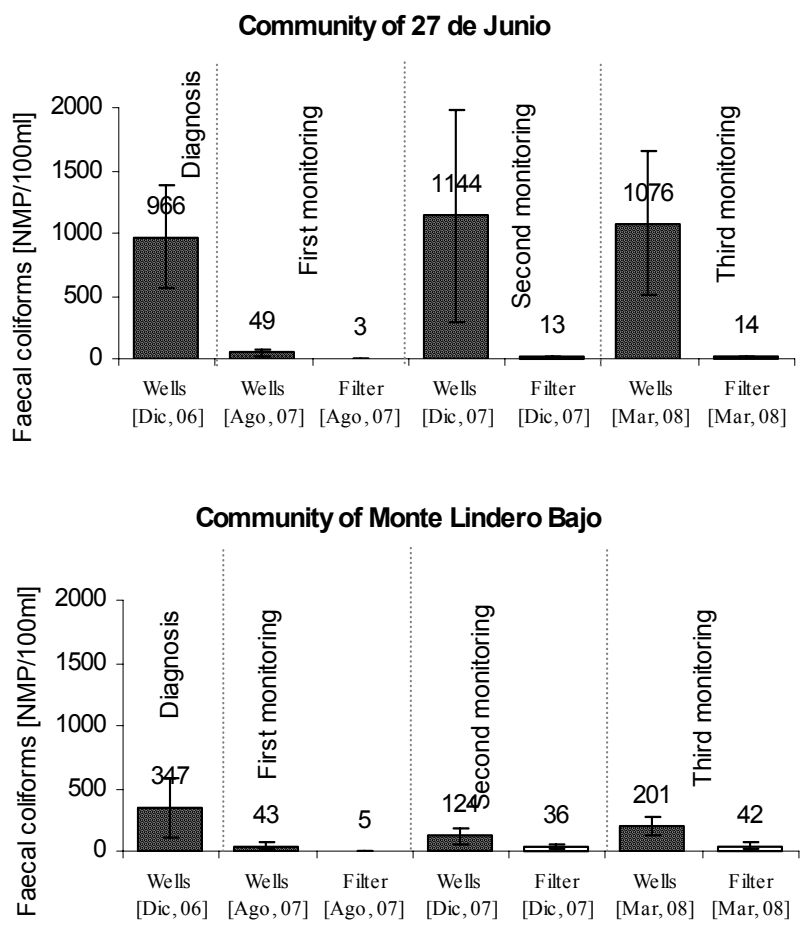

Figure 1: Water quality by source sampled in different stages of the project. The vertical lines represent the standard error of the mean.

A community-driven approach encouraged a better understanding of water management, hygiene and local constraints. We incorporated this knowledge into a health promotional campaign. Three hygiene-related actions to protect infants against diarrhea were encouraged: washing hands before preparing food and after using the toilet, safely disposing of infant feces, and safely storing water in the house to prevent microbial re-contamination (e.g. water storage using a narrow mouth container after filtration).

The acquired knowledge of health and hygiene, and community participation in all project phases, has significantly influenced these results. Figure 2 shows two selected messages by the community in the participatory workshops converted into an educational poster.

\section{Conclusions}

An analysis of interactions between the social conditions of poor shanty town dwellers on the banks of the Rimac river, their access to and use of domestic water, and the disease burden of children in these communities identify the use 


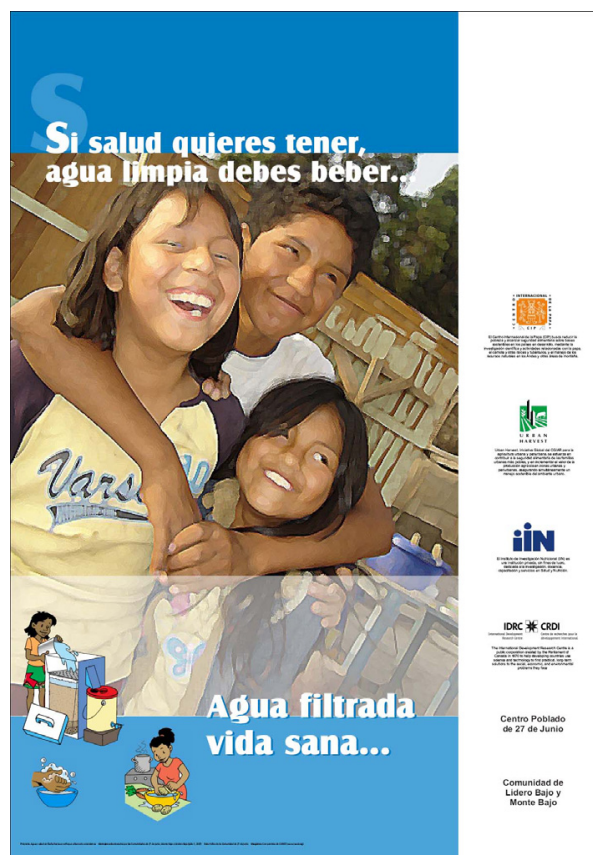

Figure 2: Selected messages by the community converted into an educational poster.

of shallow wells as an important potential source of ill-heath. Breaking this cycle through the use of simple filtering technology has had positive outcomes on local livelihoods. These are not only positive health outcomes but also opportunities for income generation as the skills acquired by community members to construct the filters is deployed by other organizations interested in scaling up this technology.

Slow sand filters had a significant improvement on water quality with a removal of up to $96.9 \%$ of fecal coliform contamination. The efficiency of water improvement trough reduction of bacterial contamination, coupled with the low cost and simple technology of these units, was seen to be a significant contribution to reducing the risk of water borne diseases and improving general health. This approach exemplifies the understanding of water management, hygienic behaviours, local constraints, and women's empowerment since water management is mainly the responsibility of women. Community participation in all project phases was essential to the success in improving sanitation with beneficial effects on health, especially of children.

\section{Acknowledgements}

This study was made possible by the International Development Research Centre's EcoHealth grant program administrated by FioCruz - Brazil. Thanks go 
to the Centre for Affordable Water and Sanitation Technology (CAWST). Our special thanks are given to Maria Moron, Mirtha Ortiz (27 de Junio) and Joaquin Villanueva (Lindero-Monte Bajo) whom leadership has significantly influenced in the communities to achieve these results.

\section{References}

[1] Acosta, L., Alvaro, H., Jiménez, H., Manrique, R. and Torralba, R. Proyecto Regional Sistemas Integrados de Tratamiento y Uso de Aguas Residuales en América Latina: Realidad y Potencial, Estudio General del Caso, Villa el Salvador, Lima, Perú, 2001

[2] Castro, M.L. and Sáenz, R. Evaluación de riesgos para la salud por el uso de aguas residuales en agricultura; aspectos microbiológicos, Centro Panamericano de Ingeniería Sanitaria y Ciencias del Ambiente (CEPIS), 1990

[3] Castro, M.L. Evaluación de riesgos para la salud por el uso de las aguas residuales en agricultura: Aspectos toxicológicos, Centro Panamericano de Ingeniería Sanitaria y Ciencias del Ambiente (CEPIS), 1993.

[4] Grasmück, D., and Scholz, R.W. 'Risk perception of heavy metal soil contamination by high exposed and low exposed inhabitants', ETH-UNS Working Papers No. 42, 2003

[5] Infante, L., and Sosa, S. Cuantificación espectro-fotométrica de arsénico en aguas de consumo humano en la vertiente del Río Rímac. Tesis presentada a la Universidad Nacional Mayor de San Marcos, Facultad de Farmacia y Bioquímica para el Grado de Químico Farmacéutico. 1994.

[6] Juarez, H. Water contamination in the Rímac River and associated water, soil and vegetable contamination in Eastern Lima, Perú. Agropolis 2. Rethinking the Role of Agriculture in Cities. Accepted for publication, 2008.

[7] Lee-Smith, D. and Prain, G. 'Urban Agriculture and Health', in C. Hawkes and M. T. Ruel, (eds) Understanding the Links Between Agriculture and Health. International Food Policy Research Institute - IFPRI. Washington, DC 20006-1002 USA, 2006.

[8] Manrique, R., Jiménez, H., Álvaro, H., Torralba, R. and Acosta, L. Estudio de Viabilidad: Sistema de Aprovechamiento de las Aguas Residuales en el Fundo San Agustín, Callao - Perú. Proyecto Regional Sistemas Integrados de Tratamiento y Uso de Aguas Residuales en América Latina: Realidad y Potencial, Convenio IDRC-OPS/HEP/CEPIS 2000-2002:86, 2002a

[9] Manrique, R., Jiménez, H., Álvaro, H., Torralba, R. and Acosta, L. 'Estudio complementario del caso fundo de San Agustín, Callao - Perú', Proyecto Regional Sistemas Integrados de Tratamiento y Uso de Aguas Residuales en América Latina: Realidad y Potencial, Convenio IDRC-OPS/ HEP/CEPIS 2000-2002, 2002b.

[10] MEM-DGAA. Evaluación ambiental territorial de la cuenca del Río Rímac. Ministerio de Energía y Minas (Dirección General de Asuntos ambientales). 1997 
[11] MINAG. Ley General de Aguas. MINAG-Dirección General de Aguas. Decreto Ley 17752:1-116. 1969.

[12] Moscoso, J. Acuicultura con aguas residuales tratadas en las Lagunas de Estabilización de San Juan, Lima, Perú. Centro Panamericano de Ingeniería Sanitaria y Ciencias del Ambiente (CEPIS). Lima, Perú. 1998.

[13] Moscoso, J. and León, G. Uso de aguas residuales, Hojas de Divulgación Técnica. Centro Panamericano de Ingeniería Sanitaria y Ciencias del Ambiente (CEPIS). Lima, Perú. 1994.

[14] World Health Organization (WHO). Guidelines for Drinking-Water Quality. 3rd Ed. Vol. 1: "Recommendations." Geneva: WHO. 2004 